\title{
IMPROVE SERVICE USER SATISFACTION AT THE INTERNATIONAL AIRPORT THROUGH FACILITIES AND QUALITY OF SERVICE
}

\author{
*Euis Saribanon', Rista Dwi Pratiwi², Chaidir Tasran³ \\ ${ }^{1,2,3}$ Institut Transportasi dan Logistik Trisakti \\ *Coresponding author. \\ E-mail addresses: nengnonon04@gmail.com
}

\begin{abstract}
ARTICLE INFO
Article history:

Received:

3 March 2021

Accepted:

15 April 2021

Available online:

4 Mei 2021

ABSTRACT

The research objective is to determine whether there is an influence of facilities and quality of domestic terminal services on service user satisfaction at El Tari Kupang International Airport in 2020. To answer the problem the author uses quantitative methods with primary data using questionnaire distribution and data management using regression analysis techniques, analysis coefficient data, multiple correlation, significant correlation test, coefficient of determination, and hypothesis testing. The results of this study are the facilities and quality of domestic terminal services jointly affect service user satisfaction shown by the multiple regression equation $\mathrm{Y}=7.169+0.214 \mathrm{X} 1+0.594 \mathrm{X} 2$, the regression equation shows there is an effect if the facilities and quality of domestic terminal services together increased service user satisfaction at El Tari Kupang International Airport will increase with a strong relationship. The strength of the relationship between these variables is positive and is at a strong level indicated by the coefficient of multiple correlation $\mathrm{R}=$ 0.799 . The contribution of facilities and quality of domestic terminal services together affect service user satisfaction by $63.8 \%$. This means that $63.8 \%$ of the value of service user satisfaction is determined by the facilities and service quality of the domestic terminal together. Whereas for the remaining $36.2 \%$ service user satisfaction is influenced by other factors not examined in this study.
\end{abstract}

Keyword: Facilities, Terminal Service Quality, Service User Satisfaction

\section{INTRODUCTION}

El Tari Kupang International Airport, formerly known as Penfui Airport, is located in the southern part of Timor Island in Kupang Regency / City, Maulava District, Penfui Village, Tuameko Village. El Tari International Airport is approximately $13 \mathrm{~km}$ from the city of Kupang and is located at an altitude of 102 meters above sea level, which is one of the gateways of transportation to and from East Nusa Tenggara.

El Tari Kupang International Airport is one of the airports managed by PT. Angkasa Pura I (Persero) is one of the companies engaged in airport services that provides facilities related to the provision of infrastructure related to company interests and the interests of service users.

The success of a company is not only seen from the availability of the necessary facilities and infrastructure, but the level of satisfaction of service users is a measure of the success or failure of the company in carrying out 
its mission. Service user satisfaction can be influenced by the provision of adequate infrastructure and service quality that can provide satisfaction to service users. Facilities in service businesses are important factors that need to be considered, especially those related to or closely related to what service users feel. Physical facilities are an indicator of whether the quality of a service is good or not, facilities are closely related to the formation of service users' perceptions. Thus, companies wishing to maintain their existence and win business competition and attract the attention of service users always provide good supporting facilities to meet their needs and realize their expectations.

However, at El Tari International Airport, Kupang, the facilities provided are sometimes considered unsatisfactory, and some weaknesses can be seen from a number of things such as the provision of trolley services which are small in number so that during busy hours there are often out of trolleys. The number of baggage collection conveyors is insufficient so that during busy hours passengers from several airlines have to queue and wait a long time, to collect baggage (not to mention in case of conveyor damage).

Furthermore, the conveyor scales at the check-in counter damage often occur such as the mismatch of passenger baggage weight with the data displayed so that complaints from passengers often occur. The capacity of the waiting room is small so it's on the clock solid some passengers do not get a seat, then the temperature in the airport waiting room is sometimes hot due to frequent damage to the AC (Air Conditioner) and frequent shutdowns of computers flight information in sections airport services, making information difficult for users of these airport services. In addition, from the point of view of services at El Tari Kupang International Airport, especially in the Terminal Area, many are deemed unsatisfactory, this can be seen from several things such as flight information computers sometimes still have boarding status while the aircraft has pushed back, this problem is caused by a lack of effective communication between information officers and Airline officers, causing frequent complaints from passengers who missed their flight.

Airport staff who are less friendly can be felt by passengers by not paying attention to passengers and greeting them when carrying out services. Furthermore, the announce voice which sometimes sounds simultaneously is because when the information officer is announcing (name calls, left behind goods) and AMC (Apron Movement Control) officers give an estimate of arrival (arrival) and landing of the aircraft and the announce voice is not too clear and unclear. heard in several parts of the airport.

The above mentioned can occur due to the lack of improvement in the facilities owned by the airport and the less than optimal quality of services provided by PT. Angkasa Pura I (Persero). Therefore, it is better if PT. Angkasa Pura I (Persero) needs to make an increase in services and additions to airport facilities in order to maximize the quality of its service to passengers, so that passengers or airport service users feel satisfied because the services provided are in accordance with their expectations, the problems that exist include lack of facilities provided by PT. Angkasa Pura I (Persero) El Tari Kupang International Airport. The problems that exist so that it is necessary to do research, among others, the less than optimal quality of services provided by PT. Angkasa Pura I (Persero) El Tari Kupang International Airport, There are passengers who complain due to frequent miscommunication of information, damage to facilities in the airport waiting room, damage to flight information computers and Announce Sounds cannot be heard in several parts of the airport.

The purpose of this study was to determine and analyze the effect of facilities and service quality together on service user satisfaction at El Tari Kupang International Airport in 2020.

\section{LITERATURE REVIEW}

According to Munawir (2018, p. 208) facilities are physical resources that must be in place before a service can be promoted to consumers. Facilities can also be anything that makes it easier for consumers to enjoy satisfaction. According to Maydiana (2019, p. 446) facilities are anything that is physical equipment and is provided by the service seller to support customer comfort. According to Yoeti (2010, p. 56) facilities are everything, both objects and services that accompany the services provided by companies, both companies. Services, trade and industrial companies. From several the definition of the above facilities, the authors can conclude that the facilities are the facilities and infrastructure that must be provided by the company before a service is offered to consumers, in order to provide maximum service to consumers or service users and to make consumers or service users feel comfortable and satisfied. Facility Indicators; The facilities of a company can be seen through its indicators. According to Tjiptono (2011, p.46) Indicators for facilities are as follows: 1) Special consideration / planning, aspects such as proportion, texture, color, etc. are considered, combined and developed to provoke intellectual and emotional responses from users or people who see it, 2) Spatial planning: This element includes interior planning and architecture, such as the placement of furniture and accessories in 
the room, circulation flow design, and others. For example, the placement of the waiting room needs to be considered in addition to its capacity, it is also necessary to pay attention to the placement of furniture or additional equipment, 3) Fittings / furnishings: Fittings / furniture function as a means of providing comfort, as a display or as a supporting infrastructure for the use of customer goods. What is meant by equipment in this research, such as: the availability of electricity, tables or chairs, internet hot spot areas, paintings or reading materials, writing utensils, etc., 3) Lighting and color: Lighting in question is the color of the room coloring and arrangement. lighting according to the nature of the activities carried out in the room and the desired atmosphere. Color can be used to increase efficiency, create a relaxed impression, and reduce accident rates. The colors used for the interior of service facilities need to be related to the emotional effect of the color chosen, 4) The messages conveyed graphically: Important and interrelated aspects of this are visual appearance, placement, choice of physical form, color selection, lighting, and choosing the form of symbols or signs used for a specific purpose. Such as photos, color images, posters, warning signs or information boards, 5) Supporting elements: The existence of main facilities will not be complete without other supporting facilities, such as: places of worship, toilets, parking lots, food and beverage locations, listening to music or watching television, wide area internet always pay attention to the level of security.

According to Tjiptono (2017, p.22) Service Quality is conformity to requirements or demands, suitability for continuous use and repair, free from damage or defects, fulfillment of customer needs, doing everything that is happy. According to Feigenbaum in Nasution \& Mudjahidin (2013, p.41) Service Quality is satisfaction full customer (full customer satisfaction). A service is said to be of quality if it can provide full satisfaction to consumers, that is, in accordance with what consumers expect for services, both products and services offered. Then According to Asrizal, Efendy, Nasution, Muhammad and Taufik (2018, p. 43) Service Quality is a dynamic condition relating to products, people or labor, processes and tasks and the environment that meets or exceeds customer expectations.

Furthermore, Rahmawati (2016, p.5) Service Quality is any action or deed that is offered by one party to another. Quality service is a good service or product that exceeds customer expectations at a certain time so that customers have a response to a service they have felt. According to A. Wibowo (2014, p.72) Service Quality is a comparison between services that are felt to be the same or exceed the expected service quality, so the service can be said and has quality.

From several definitions of service quality above, the authors can conclude that service quality is any action or activity that a company can offer to consumers or service users, which are basically intangible and do not result in any ownership but can provide satisfaction to consumers or service users.

According to Sukmawati (2015, p.67), revealed that there are five dimensions used to measure service quality, namely; 1) Tangible, namely the appearance of the physical facilities, equipment, employees, and installed materials. Describe the physical form and services that will be received by consumers. Examples include the condition of the building, restaurant facilities, restaurant design, and the neatness of the appearance of employees at a certain time so that customers have a response to a service they have felt. According to A. Wibowo (2014, p.72) Service Quality is a comparison between services that are felt to be the same or exceed the expected service quality, so the service can be said and has quality. From the several definitions of service quality above, the authors can conclude that service quality is any action or activity that a company can offer to consumers or service users, which are basically intangible and do not result in any ownership but can provide satisfaction to consumers or users.

According to Hardiansyah (2018, p.41) states that service quality can be measured from 5 dimensions, namely: Tangible, Reliability, Responsiveness, Assurance, and Emphaty (Empathy). Each dimension has the following indicators: For the Tangible dimension, it consists of indicators; 1) The appearance of officers / apparatus in serving customers, 2) Convenience of the place to do services, 3) Discipline of officers / apparatus in providing services, 4) Ease of processing and service access, 5) The use of tools in service, 6) For the dimension of Reliability (reliability), consisting of indicators: 1) Accuracy of officers in serving customers, 2) Having clear service standards; 3) The ability of officers / apparatus in using tools in the service process, 4) Expertise of officers in using tools in the service process, 4) For the dimensions of Responsiveness (Response), consisting of indicators; 1) Respond everytime customers \& applicants who want to get service, 2) The officer / apparatus performs services quickly and accurately, 3) The officer / apparatus performs services carefully, 3) All customer complaints are responded to by the officer For the Assurance dimension, consisting of indicators: 1) The officer guarantees on time in service, 2 ) Officers guarantee legality in services, 3) Officers guarantee certainty of costs in services. 
For the Emphaty dimension (Empathy), it consists of indicators: 1) Prioritizing the interests of the applicant \& customer. 2) Officers serve with a friendly attitude, 3) Officers serve with courtesy, 4) Officers serve in a non-discriminatory manner (differentiate, 5) Officers serve and respect each customer.

According to Tjiptono (2017, p.54) that customer satisfaction or dissatisfaction is the customer's response to the evaluation of a mismatch or disconfirmation, which is felt between previous expectations or other performance norms and the actual performance of the product that is felt after its use. According to Oktaviani, Utami and Susanto (2018, p.48) Customer Satisfaction is an emotional response to experiences related to certain products or services purchased, retail outlets, or even behavior patterns.

Meanwhile, according to Nasution $(2014$, p. 56) customer satisfaction can be defined simply, which is a condition in which the needs, wants and expectations of customers can be fulfilled through the products or services that are consumed.

Meanwhile, according to Suharto (2015, p. 51) customer satisfaction is a condition that describes the fulfillment, even exceeding of customer expectations for a product or service carried out by the producer / business actor.

\section{METHODS}

The research method in this study is the Descriptive Quantitative Method, and the data analysis technique used in this study is carried out with a quantitative approach, namely the analysis technique uses the data or information needed to explain the variables studied using statistical models, namely: Analysis techniques The data used in this paper are as follows Instrument Calibration (Validity Test and Reliability Test), Linear Regression Analysis, Correlation Analysis, Determinant Coefficient or Determining Coefficient, $\mathrm{t}$ test and $\mathrm{f}$ test. The population of data in this study were all domestic passengers at El Tari International Airport in Kupang within 1 year, namely 1,851,279 passengers in 2019 .

\section{RESULT AND DISCUSSION}

In conducting a study, the author used an online questionnaire that was distributed to users of El Tari Kupang International Airport, PT. Angkasa Pura I (Persero) especially at the Domestic Terminal. The questionnaire that the author distributes is 100 questionnaires based on the calculation of the sample taken through the Slovin formula to the entire population. The following is the data processed in the form of a questionnaire, in which there is a respondent's identity in the form of gender, age of the respondent, last education and length of work of the respondent to represent the population under study.

The measurement of the validity of the questionnaire items of this study was carried out by looking at the Pearson Correlation coefficient of 100 respondents. With a total sample of 100 respondents, the value of the rtable is $\mathrm{df}=(\mathrm{N}-2)$ then $\mathrm{df}=(100-2)$ and it can be obtained $\mathrm{df}=98$, then the rtable value is 0.196 . The validity requirement is rcount $>$ rtable. If these requirements do not meet the requirements, then the questionnaire items must be deleted and no longer used in further analysis. Validity testing is carried out for each statement item from the Facility variable (X1), Domestic Terminal Service Quality (X2) and Service User Satisfaction (Y). The validity test of this research is by measuring the degree of correlation between each question item on each variable.

\section{Facility Variable (X1)}

All statement items were declared valid because each Pearson correlation or rcount> rtable, and the significance level $>0.05$. For rtabel 0.196 it is obtained from the $r$ statistical table. The author uses a significance level for the two-way test ( 2 tailed) with a significance level of 0.05 , the following results are obtained:

Table 1. Table Facility Variable Validity Test $\left(\mathrm{X}_{1}\right)$

\begin{tabular}{cccc}
\hline & Item-Total Statistics & & \\
\hline & $\begin{array}{c}\text { Corrected } \\
\text { Item-Total } \\
\text { Correlation }\end{array}$ & r table & Validity \\
& 0.538 & 0.196 & VALID \\
\hline Statement X1.1 & 0.349 & 0.196 & VALID \\
\hline Statement X1.2 & 0.733 & 0.196 & VALID \\
\hline Statement X1.3 & 0.612 & 0.196 & VALID \\
\hline Statement X1.4 & & & \\
\hline
\end{tabular}


JEMEB | Volume 1, Issue 1 (2021) | 58-65

\begin{tabular}{cccc}
\hline Statement X1.5 & 0.592 & 0.196 & VALID \\
\hline Statement X1.6 & 0.727 & 0.196 & VALID \\
\hline Statement X1.7 & 0.692 & 0.196 & VALID \\
\hline Statement X1.8 & 0.616 & 0.196 & VALID \\
\hline Statement X1.9 & 0.717 & 0.196 & VALID \\
\hline Statement X1.10 & 0.659 & 0.196 & VALID \\
\hline
\end{tabular}

Variable Quality of Domestic Terminal Services (X2)

All statement items were declared valid because each Pearson correlation or rcount $>$ rtable, and the significance level was $<0.05$. For rtabel 0.196 it is obtained from the $\mathrm{r}$ statistical table. The author uses a significance level for the two-way test ( 2 tailed) with a significance level of 0.05 , which is as follows:

Table 2. Table Validity Test of Domestic Terminal Service Quality Variables (X2)

\begin{tabular}{lccl}
\hline \multicolumn{4}{c}{ Item-Total Statistics } \\
Statement & $\begin{array}{c}\text { Corrected } \\
\text { Item-Total } \\
\text { Correlation }\end{array}$ & r table & Validity \\
\hline Statement X2.1 & 0.671 & 0.196 & VALID \\
\hline Statement X2.2 & 0.704 & 0.196 & VALID \\
\hline Statement X2.3 & 0.665 & 0.196 & VALID \\
\hline Statement X2.4 & 0.724 & 0.196 & VALID \\
\hline Statement X2.5 & 0.722 & 0.196 & VALID \\
\hline Statement X2.6 & 0.682 & 0.196 & VALID \\
\hline Statement X2.7 & 0.616 & 0.196 & VALID \\
\hline Statement X2.8 & 0.626 & 0.196 & VALID \\
\hline Statement X2.9 & 0.666 & 0.196 & VALID \\
\hline Statement X2.10 & 0.584 & 0.196 & VALID \\
\hline
\end{tabular}

Service User Satisfaction Variable (Y)

All statement items were declared valid because each Pearson correlation or rcount $>$ rtabel, and the significance level $>0.05$. For rtabel 0.196 it is obtained from the $r$ statistical table. The author uses a significance level for the two-way test ( 2 tailed) with a significance level of 0.05 , which is as follows:

Table 3. Table Validity Test of Service User Satisfaction Variables (Y) Item-Total Statistics

\begin{tabular}{lccl}
\hline Statement & $\begin{array}{c}\text { Corrected } \\
\text { Item-Total } \\
\text { Correlation }\end{array}$ & r table & Validity \\
\hline Statement Y.1 & 0.581 & 0.196 & VALID \\
\hline Statement Y.2 & 0.698 & 0.196 & VALID \\
\hline Statement Y.3 & 0.722 & 0.196 & VALID \\
\hline Statement Y.4 & 0.736 & 0.196 & VALID \\
\hline Statement Y.5 & 0.725 & 0.196 & VALID \\
\hline Statement Y.6 & 0.627 & 0.196 & VALID \\
\hline Statement Y.7 & 0.653 & 0.196 & VALID \\
\hline Statement Y.8 & 0.639 & 0.196 & VALID \\
\hline Statement Y.9 & 0.640 & 0.196 & VALID \\
\hline Statement Y.10 & 0.473 & 0.196 & VALID \\
\hline
\end{tabular}

Structure of the Influence of Facility Variables (X1) on Service User Satisfaction Variables (Y)

Simple Regression Analysis 
Simple regression analysis aims to determine whether these two variables have a significant linear relationship or not. Furthermore, the calculation is carried out using the IBM SPSS Statistics V25 software, the following results are obtained:

\section{Tabel 4. Simple Regression Analysis for Facility Variables $\left(\mathrm{X}_{1}\right)$ on Service User Satisfaction Variables (Y)}

\section{Coefficients $^{\mathrm{a}}$}

\begin{tabular}{|c|c|c|c|c|c|}
\hline \multirow{3}{*}{ Model } & \multicolumn{2}{|c|}{$\begin{array}{r}\text { Unstandardied } \\
\text { Coefficients } \\
\end{array}$} & \multirow{2}{*}{$\begin{array}{r}\text { Standardized } \\
\text { Coefficients }\end{array}$} & \multirow[b]{3}{*}{$\mathrm{t}$} & \multirow[b]{3}{*}{ Sig. } \\
\hline & B & Std. Error & & & \\
\hline & & & & & \\
\hline 1 (Constant) & 7.169 & 3.500 & & 2.048 & .043 \\
\hline Facility (X1) & .214 & .085 & .20 & 2.502 & .014 \\
\hline $\begin{array}{l}\text { Service Quality Domestic } \\
\text { Terminal (X2) }\end{array}$ & .594 & .083 & .58 & 7.155 & .000 \\
\hline
\end{tabular}

a. Dependent Variable: Service User Satisfication (Y)

Source: Data 2020

$$
\begin{gathered}
\mathrm{Y}=\mathrm{a}+\mathrm{bX} 1+\mathrm{BX} 2 \\
\mathrm{Y}=7,169+0,214 \mathrm{X} 1+0,594 \mathrm{X} 2
\end{gathered}
$$

1) A constant value of 7,619 means that the Service User Satisfaction Variable at the Domestic Terminal of El Tari International Airport is 7,619 units. With the assumption of Facility Variables and Service Quality Variables of Domestic Terminals at El Tari International Airport in a constant state or if $\mathrm{X}=0$.

2) The multiple regression equation can be used because it has met the requirements where the multiple regression equation shows the Facility Variables and Domestic Terminal Service Quality Variables on Service User Satisfaction are unidirectional (positive), this is shown in the regression coefficient or the B value in the regression equation. shows a positive number, the Facility is 0.214 while the Domestic Terminal Service Quality is 0.594 which means that any increase in the Facilities and Quality of Domestic Terminal Service 1 unit will be followed by an increase in ship Service User Satisfaction of 7,619 units.

Thus, the meaning and linearity test is carried out to find out that the multiple regression equation that has been tested can be used.

Furthermore, to determine the nature of the relationship and the strength of the relationship between the Facility variable (X1) and the Domestic Terminal Service Quality (X2) on the Service User Satisfaction (Y) variable, the calculation of the correlation with the SPSS V25 program produces the following picture:

Table 5. Multiple Correlation of Facilities $\left(X_{1}\right)$ and Domestic Terminal Service Quality $\left(X_{2}\right)$ Against Service User Satisfaction (Y)

\begin{tabular}{|c|c|c|c|c|c|c|}
\hline Model & & Sum of Squares & $\mathrm{df}$ & Mean Square & $\mathrm{F}$ & Sig. \\
\hline \multirow[t]{3}{*}{1} & Regression & 1977.916 & 2 & 988.958 & 6.453 & $.450^{\mathrm{b}}$ \\
\hline & Residual & 2065.074 & 97 & 21.289 & & \\
\hline & Total & 4042.990 & 99 & & & \\
\hline
\end{tabular}

ANOVA $^{\mathrm{a}}$

a. Dependent Variable: User Satisfication (Y)

b. Predictors: (Constant), Services Quality Domestic Terminal $\left(\mathrm{X}_{2}\right)$, Facility $\left(\mathrm{X}_{1}\right)$

Sumber: Data telah diolah penulis 2020

In table 1.7 above, the writer conducted the $\mathrm{f}$ test to test the overall variables where the variables $\mathrm{X} 1$ and $\mathrm{X} 2$ gave a relationship to variable $\mathrm{Y}$ together. Where in this $\mathrm{f}$ test there is a formulation of hypotheses, namely: H0: $\alpha=0$ (no relationship) and Ha: $\alpha \neq 0$ (there is a relationship). As well as the existence of decision rules, 
such as acceptance of H0 if Fcount $>$ Ftable the data above is obtained from the regression analysis conducted by the author and from this analysis it is known that Fcount is 6.45 which is obtained from the formula:

Ftable $=\mathrm{n}-\mathrm{k}-1$ Information:

$\mathrm{n}=$ Total Respondents $\mathrm{k}=$ Independent Variable

Ftable $=100-2-1$ Ftable $=3.09$

The data also obtained from the analysis, namely Fcount is 6.45. So, Fcount $>$ Ftable which is $6.453>3.09$ proves that Ho is rejected and Ha is accepted.

\section{CONCLUSION AND RECOMMENDATION}

Based on the results of the interpretation, it can be seen that the Facility variable (X1) to the Service User Satisfaction variable (Y) is $34.6 \%$ in the interval $0.40-0.599$ the coefficient is interpreted to have a moderate level of influence. So it can be interpreted that there is an influence between the Facility variable (X1) on the Service User Satisfaction variable $(Y)$ in a positive direction. Based on the interpretation results it can be seen that the Domestic Terminal Service Quality variable (X2) on the Service User Satisfaction variable (Y) is 45.5 $\%$ is in the interval $0.60-0.799$ interpreted to have a strong level of influence. So it can be interpreted that there is a strong influence between Domestic Terminal Service Quality (X2) on the Service User Satisfaction variable (Y) in a positive direction.,

With the conclusion that the results of interpretation simultaneously (together), where the results between the Facility Variable (X1) and Domestic Terminal Service Quality (X2) on the Service User Satisfaction variable (Y) have a result of $63.8 \%$ in the coefficient interval 0,60-0.799 which can be interpreted as a strong influence so that it has a positive value. So it can be interpreted that all the hypotheses that the authors examined in this study are true because they have been proven and tested in this study.

\section{REFERENCES}

Andri. (2016). Pelayanan Bandar Udara Halim Perdana Kusuma dan Bandar Udara Husein Sastranegara. Manajemen Transportasi \& Logistik, 03.

Asrizal, Efendy, Nasution, Muhammad, Taufik, L. (2018). Pengaruh Harga dan Kualitas Pelayanan Terhadap Keputusan Pembelian Konsumen (Studi Kasus pada Alfamart di Kota Medan). Proseding Seminar Nasional Vokasi Indonesia. Boni Arionasti. (2014). Pengaruh Fasilitas di Ruang Tunggu terhadap Tingkat Kepuasan Penumpang di Bandara Internasional Ahmad Yani Semarang.

Bandung: Alumni.

Hardiansyah. (2011). Kualitas Pelayanan Publik. Yogyakarta: Gava Media. Hardiansyah. (2018). Kualitas Pelayanan Publik: Konsep, Dimensi, Indikator, dan Implementasinya. Gava Media.

Imam, G. (2011). Aplikasi Analisis Multivariate Dengan Program SPSS. Semarang: Badan Penerbit Universitas Diponegoro.

Isa, M., Lubis, H. A., \& Chaniago, M. (2019). Pengaruh Kualitas Pelayanan Terhadap Kepuasan Penumpang Menggunakan Jasa Angkutan Penyeberangan PT. ASDP Indonesia Ferry (Persero) Cabang Sibolga. Jesya (Jurnal Ekonomi \& Ekonomi Syariah), 2(2), 164-181.

Jurnal Ground Handling Dirgantara, 1, 11.

Manajemen Bisnis Transportasi Dan Logistik, 2, 9.

Maydiana, L. (2019). Pengaruh Kualitas Pelayanan dan Fasilitas terhadap Kepuasan Pelanggan pada Jasa Cuci Motor Mandiri . (Jurnal Ekonomi \& Ekonomi Syariah), 2(4), 132-174

Menteri. (2015). Peraturan Menteri Perhubungan No 38 Tahun 2015 Standar Pelayanan.

Menteri. (2015). Peraturan Menteri Perhubungan No 77 Tahun 2015 Sertifikasi Fasilitas.

Munawir. (2018). Pengaruh Kualitas Pelayanan Dan Fasilitas Terhadap Kepuasan Konsumen Foto Copy Awy Comp Di Pondok Pesantren Darussalam Blok Agung Tegalsari Banyuwangi. Hukum Islam,Ekonomi Dan Bisnis, 4(2), 204-215.

Nasution, M., \& Mudjahidin. (2013). Analisis Kualitas Layanan Website Kantor Pelayanan Perbendaharaan Negara [KPPN] Surabaya I Dengan Menggunakan Webqual. Seminar Nasional Sistem Informasi Indonesia.

Nasution. (2014). Manajemen Jasa Terpapadu. Bogor: Ghalia Indonesia. Nazir. (2011). Metodologi Penelitian. 
Bogor: Ghalia Indonesia.

Oktaviani, P., Utami, S., \& Susanto, B. (2018). Pengaruh Kualitas Pelayanan Terhadap Kepuasan Konsumen Pada Layanan Pos Express Pt. Pos Indonesia (Persero) Kantor Pos Kediri Kota. JIMEK : Jurnal Ilmiah Mahasiswa Ekonomi, 1(1).

Puspita, R. M., \& Santoso, S. (2018). Pengaruh Kualitas Pelayanan Dan Fasilitas Pendukung Terhadap Kepuasan Pelanggan Stasiun Lempuyangan Yogyakarta. Eksis: Jurnal Riset Ekonomi Dan Bisnis, 13(1), 69-80.

Putrie. (2016). Metodologi Penelitian Kuantitatif. Jakarta: Mitra Wacana Media.

Rahmawati, D. (2016). Pengaruh Kualitas Pelayanan, Kualitas Produk dan [romosi terhadap Kepuasan Konsumen di Wedding Organizer (Studi Kasus "Pixtira Salon") di Desa Gampengrejo Kabupaten Kediri. Universitas Nusantara PGRI Kediri.

Sugiyono. (2016). Metodologi Penelitian Kuantitatif. In CV Alfabeta.

Suharto. (2015). Coustemer Service dalam Jasa Transportasi. Jakarta: Rajawali Pers.

Sukmawati, I. (2015). Pengaruh Kualitas Pelayanan Dimediasi Kepuasan Pelanggan dan Kepercayaan Pelanggan terhadap Loyalitas Pelanggan pada PT. Air Manado. Jurnal Riset Ekonomi, Manajemen, Bisnis Dan Akuntansi.

Tjiptono, dan C. (2011). Service, Quality \& satisfaction (Edisi 2). Yogyakarta: Penerbit Andi Yogyakarta.

Tjiptono. (2017). Analisis Perbedaan Kualitas Pelayanan \& Kepuasan. Young Consumers.

Wibowo, A. (2014). Pengaruh Kualitas Pelayanan Transportasi Umum Bus Trans Jogja terhadap Kepuasan Konsumen. Jurnal Ilmu Manajemen.

Yoeti. (2010). Dasar-Dasar Pengertian Hospitaliti Dan Pariwisata (Edisi 1).

Yuzal, I. (2016). Pelayanan Fasilitas Terminal Bagi Pengguna Jasa Penerbangan.

Zulaichah. (2014). Pengaruh Fasilitas Bandar Udara Terhadap Kinerja Ketepatan Waktu Maskapai Penerbangan. Perhubungan Udara. 